\title{
Chemical Analysis of High-Level Radioactive Waste Glass by ICP-AES
}

\author{
Tsunetaka BAnbA*, Hiromichi HagiYA*, Yukito TAMURA*, Muneaki Senoo**, \\ Chushiro Yonezawa* and Paul B. CARTER*** \\ *Japan Atomic Energy Research Institute, Tokai, Ibaraki 319-11, Japan \\ **Radioactive Waste Management Center, 2-8-10, Toranomon, Minato, Tokyo 105, Japan \\ ***British Nuclear Fuels plc, Risley, Warrington, Cheshire, WA3 6AS, England
}

\begin{abstract}
The chemical composition of the high-level radioactive waste glass which was produced in the Windscale Vitrification Plant at Sellafield was determined by ICP-AES. The chemical analysis was performed in shielded cells and glove boxes at the Japan Atomic Energy Research Institute. The sample was dissolved by alkaline fusion with sodium peroxide and acidic decomposition with hydrofluoric and perchloric acids for determining $\mathrm{Si}$ and $\mathrm{B}$, and $\mathrm{Li}, \mathrm{Na}, \mathrm{Mg}, \mathrm{Al}, \mathrm{P}, \mathrm{Cr}, \mathrm{Fe}, \mathrm{Ni}$, $\mathrm{Sr}, \mathrm{Zr}, \mathrm{Mo}, \mathrm{La}, \mathrm{Ce}, \mathrm{Nd}$ and $\mathrm{U}$, respectively. High accuracy of the analytical results was confirmed by analyzing the reference material of glass (NIST SRM1412) and a simulated inactive waste glass. The analytical results of the high-level radioactive waste glass were in good or fair agreement with the values estimated by British Nuclear Fuels plc, which were calculated from the analytical data of the high-level radioactive liquid waste and glass frit used in the production of the radioactive waste glass.
\end{abstract}

Keywords High-level radioactive waste glass, ICP-AES, alkaline fusion, acidic decomposition, reproducibility, accuracy

In a reprocessing plant for spent nuclear reactor fuel, the spent fuel is dissolved in concentrated nitric acid solution, and plutonium and unburned uranium are removed in the chemical separation process. The remaining solution contains more than $99 \%$ of the nonvolatile fission product elements, impurities from the cladding materials, corrosion products, traces of unseparated plutonium and most of the transuranic elements. This reprocessing waste is called high-level radioactive liquid waste (HLLW). The HLLW is generally concentrated by evaporation and stored as an aqueous nitric acid solution in high-integrity stainless-steel tanks. Internationally, glass is the material of choice for incorporating and immobilizing the hazardous radionuclides in HLLW because of the good product durability and technical maturity. Recently, the HLLW arising from the commercial reprocessing plants were converted into borosilicate glasses in the vitrification plants in France (in the R7 and T7 Vitrification Plants at La Hague), and in the UK (in the Windscale Vitrification Plant (WVP) at Sellafield). ${ }^{1}$ Part of the vitrified products produced at La Hague have been already returned to Japan and the products vitrified at Sellafield will be returned to Japan in the near future, according to the agreements between the Japanese electric power companies and Compagnie Generale des Matieres Nucleaires (COGEMA) or British Nuclear Fuels plc (BNFL) for the reprocessing of irradiated oxide fuel. In these situations, it is necessary to confirm the general characteristics of these vitrified products. At the Japan Atomic Energy
Research Institute (JAERI), a series of characterization tests (chemical analysis, heat load measurement, leaching test, homogeneity and devitrification test) on the radioactive samples of vitrified residues were performed in cooperation with Commissariat a l'Energie Atomique (CEA), COGEMA and BNFL with the support of Science and Technology Agency (STA). ${ }^{2}$

The chemical analysis of the vitrified products produced in the industrial vitrification plant is one of the most important subjects in the characterization tests, because the analytical data are effective for the confirmation of the agreement between the industrial product and designed product. However, the chemical analysis of industrial vitrified product has never been carried out in other countries. In our previous study, an analytical method was developed and evaluated by using inactive samples for supporting the characterization tests of actual high-level radioactive waste glass. ${ }^{3}$ The good accuracy of the method was demonstrated by the analytical data of the simulated inactive waste glass sample and several reference materials of glasses (National Institute of Standards and Technology: NIST SRM). Thereafter, this analytical method was modified slightly from the standpoints of the remote sample preparation in the shielded cells (e.g. use of devices and equipment protected from breaking) and the improvement of ICPAES (e.g. determination of $\mathrm{Li}$ and $\mathrm{Na}$ by the addition of a monochromator for long wavelengths). The following elements were selected for the determination from the standpoint of the effects on homogeneity, thermal 
stability and chemical durability of vitrified product: $\mathrm{Si}$, $\mathrm{B}, \mathrm{Na}$ as main components of glass; $\mathrm{Li}, \mathrm{Al}$ as additives; $\mathrm{Mg}, \mathrm{P}, \mathrm{Cr}, \mathrm{Fe}, \mathrm{Ni}, \mathrm{Zr}$ as process inerts; $\mathrm{Sr}, \mathrm{Mo}, \mathrm{La}, \mathrm{Ce}$, $\mathrm{Nd}, \mathrm{U}$ as fission product and fuel elements.

In the present paper, the modified analytical method and results of chemical analysis for an radioactive waste glass sample which was taken during routine production in the WVP in 1993 are described. On the basis of analytical results, the applicability of the present method to the high-level radioactive waste glass is discussed. The analytical results are also compared with the data estimated by the waste glass producer, BNFL.

\section{Analytical Method}

\section{Standard solutions}

The following five kinds of standard solutions were prepared for the determination of each element. The range of concentration for each element is shown in parentheses.

(1) Silicon $\left(10-40 \mathrm{~g} / \mathrm{m}^{3}\right)$ and (2) boron $(0.5-10$ $\left.\mathrm{g} / \mathrm{m}^{3}\right)$ : The commercial standard solutions of 1 g-each element $/ \mathrm{dm}^{3}$ (Kanto Chemical Co., Inc.) were diluted with $0.025 \mathrm{~mol} / \mathrm{dm}^{3}$ sodium hydroxide $(\mathrm{NaOH})$ solution, respectively. The sodium hydroxide concentration of diluent was decided by the Na concentration of dissolved solution prepared by alkaline fusion of glass samples.

(3) Sodium, $\mathrm{Mg}, \mathrm{Al}, \mathrm{Fe}$ and $\mathrm{Zr}\left(0.5-10 \mathrm{~g} / \mathrm{m}^{3}\right)$ and (4) chromium, Sr, Mo, La (0.5 - $\left.10 \mathrm{~g} / \mathrm{m}^{3}\right)$, Li, Ni, Ce, Nd (1 $\left.-20 \mathrm{~g} / \mathrm{m}^{3}\right), \mathrm{P}\left(1-5 \mathrm{~g} / \mathrm{m}^{3}\right)$ : The solution of $0.36 \mathrm{~mol} / \mathrm{dm}^{3}$ perchloric acid $\left(\mathrm{HClO}_{4}\right)-0.6 \mathrm{~mol} / \mathrm{dm}^{3}$ hydrochloric acid $(\mathrm{HCl})$ was used for diluting the commercial standard solutions of $1 \mathrm{~g}$-each element $/ \mathrm{dm}^{3}$ (Kanto Chemical Co., Inc.). The concentrations of perchloric acid and hydrochloric acid were decided by the acid concentrations of dissolved solution prepared by acidic decomposition of glass samples.

(5) Uranium $\left(0.5-5 \mathrm{~g} / \mathrm{m}^{3}\right)$ : The stock solution of 0.1 $\mathrm{g}-\mathrm{U} / \mathrm{m}^{3}$, which was previously prepared by the dissolution of natural uranium at JAERI, was diluted with the same solution as the standard solutions (3) and (4) were prepared.

\section{Samples}

The radioactive waste glass sample (WVP-waste glass sample) was taken from a normal production run on the WVP at Sellafield on 20th January, 1993. One pour was made, during which 273.5 liters of HLLW was transferred to the calciner and $145.9 \mathrm{~kg}$ of glass frit was added to the melter. The sample was taken from this vitrified product by the sampling device designed. The sample was contained within a stainless-steel tube of $150 \mathrm{~mm}$ length with an internal diameter of $16 \mathrm{~mm}$ and $20 \mathrm{~mm}$ external diameter. The weight of the WVPwaste glass sample was about $80 \mathrm{~g}$.

The Japan Atomic Energy Research Institute received the WVP-waste glass sample from BNFL. This sample was cut into 7 sections in a shielded cell of the Waste Safety Testing Facility (WASTEF) at JAERI and section " $\mathrm{B}$ " was used for the chemical analysis (Fig. 1). At first, the cylindrical sample "B" was cut into $8 \mathrm{sec}$ tions and then each one was cut into squares $(8 \times 8 \mathrm{~mm})$ as shown by hatched lines in Fig. 1 in order to remove the steel sleeve together with the reacted layer on the glass/steel interface. Eight glass samples of $1.5 \mathrm{~g}$ square disks were transferred into an agate ball mill and ground into powder.

As reference samples, the reference material of glass (NIST SRM1412) and a simulated inactive waste glass were subjected to the chemical analysis. Since the NIST SRM1412 contains several typical elements incorporated in the waste glass, it was used as a reference sample. The simulated inactive waste glass sample was produced on the Full Scale Inactive Facility of BNFL at Sellafield.

\section{Decomposition of samples}

Decomposition by alkaline fusion. For the determination of Si and B, the powdered glass sample was decomposed by alkaline fusion with sodium peroxide $\left(\mathrm{Na}_{2} \mathrm{O}_{2}\right)$. A sample of $0.1 \mathrm{~g}$ (particle size $<0.33 \mathrm{~mm}$ ) was well mixed with $1.5 \mathrm{~g}$ of sodium peroxide in a zirconium crucible. The crucible covered with a lid was heated in an electric furnace at $700^{\circ} \mathrm{C}$ for $3-5 \mathrm{~min}$. After cooling, the crucible and lid were transferred to a beaker. A seventy milliliter aliquot of pure water was added to the beaker and heated on a hot plate for about one hour at $80-90^{\circ} \mathrm{C}$ in order to dissolve the melt. A small amount of precipitate was formed in the solution during this operation. The precipitation probably results from the formation of hydroxides such as $\mathrm{Fe}$ and $\mathrm{Zr}$, because these ions easily precipitate by the hydrolysis in an alkaline solution. After filtering (using a 0.45 $\mu \mathrm{m}$ Milli Pore filter), the precipitates were dissolved with $10 \mathrm{~cm}^{3}$ of $6 \mathrm{~mol} / \mathrm{dm}^{3}$ hydrochloric acid at 60 $70^{\circ} \mathrm{C}$. The filtrate and dissolved solution were separately transferred into a volumetric flask and made up to $100 \mathrm{~cm}^{3}$ with pure water. Both the diluted solutions

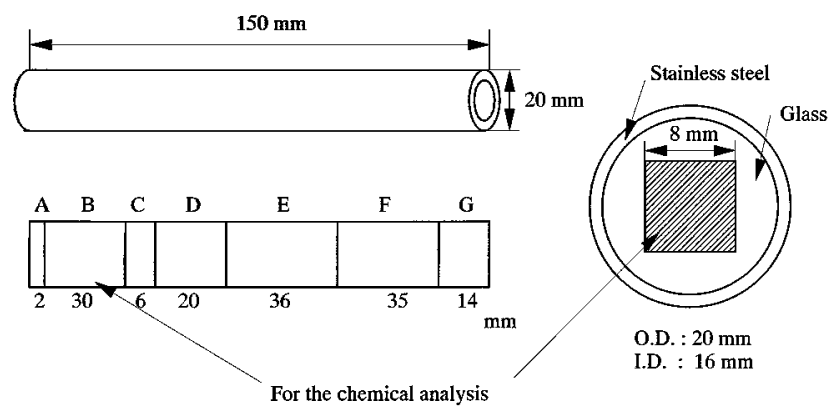

Fig. 1 Appearance of the WVP-radioactive waste glass sample. Square disks of section "B" were used for the chemical analysis. Other 6 sections were used for other characterization tests. 
were used for the determination of $\mathrm{Si}$ and $\mathrm{B}$. The oxide content (wt\%) of each element was calculated from the sum of the amount in the filtrate and that in the precipitates. The procedure of decomposition of the WVPwaste glass sample by alkaline fusion is shown in Fig. 2.

Acidic decomposition. For the determination of the major elements including $\mathrm{Li}, \mathrm{Na}, \mathrm{Mg}, \mathrm{Al}, \mathrm{P}, \mathrm{Cr}, \mathrm{Fe}, \mathrm{Ni}$, $\mathrm{Sr}, \mathrm{Zr}, \mathrm{Mo}, \mathrm{La}, \mathrm{Ce}, \mathrm{Nd}$ and $\mathrm{U}$, the sample was decomposed with hydrofluoric acid (HF) and perchloric acid $\left(\mathrm{HClO}_{4}\right)$. One cubic centimeter of pure water, $5 \mathrm{~cm}^{3}$ of $46 \%$ hydrofluoric acid and $5 \mathrm{~cm}^{3}$ of $60 \%$ perchloric acid solution were poured over a $0.1 \mathrm{~g}$ sample (particle size $<0.33 \mathrm{~mm}$ ). The mixture was heated in a platinum dish on a hot plate until a practically clear solution was formed, then the temperature was raised and the solution was heated until white fumes were evolved. After cooling, $5 \mathrm{~cm}^{3}$ of $46 \%$ hydrofluoric acid and $5 \mathrm{~cm}^{3}$ of concentrated nitric acid were added to the residue and the residue was digested at $160^{\circ} \mathrm{C}$. After repeating this process three times, the solution was heated on a hot plate until white fumes were evolved. After cooling, $10 \mathrm{~cm}^{3}$ of $6 \mathrm{~mol} / \mathrm{dm}^{3}$ hydrochloric acid was added and the residue was digested at $80^{\circ} \mathrm{C}$. A small insoluble residue remained in this solution. After filtering by using a $0.45 \mu \mathrm{m}$ Milli Pore filter, the residue was decomposed by the fusion technique described above (by using a nickel crucible instead of a zirconium crucible), and the elements contained in the residue were determined. Meanwhile, the filtrate was transferred into a volumetric flask and made up to $100 \mathrm{~cm}^{3}$ with pure water. The oxide content (wt \%) of each element was calculated from the sum of the amount in the filtrate and that in the residue. The procedure for acidic decomposition of the WVP-waste glass sample is shown schematically in Fig. 3.

The grinding and decomposition of the sample were carried out in a shielded cell at JAERI. The reference

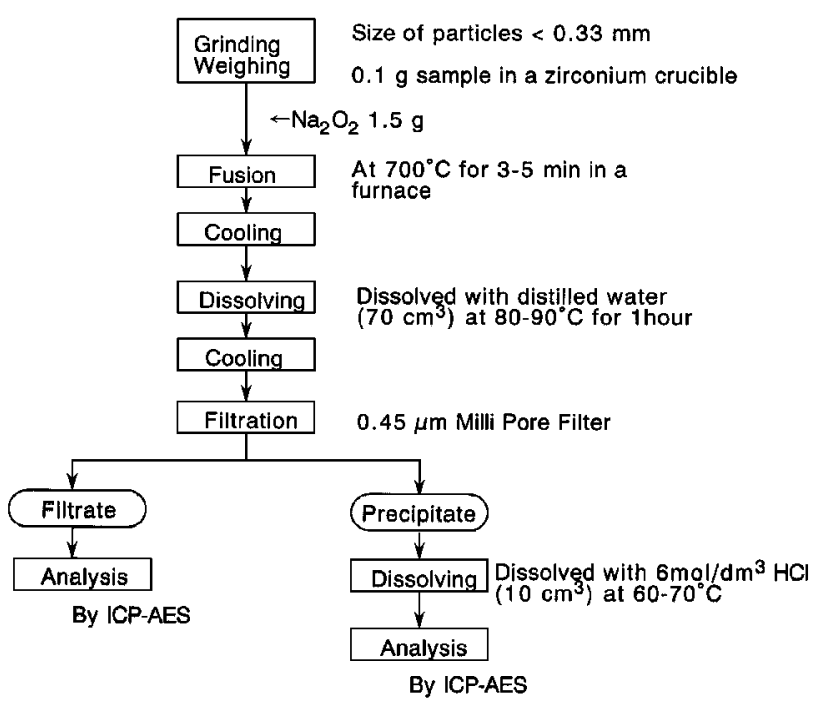

Fig. 2 Procedure of alkaline fusion technique for determination of silicon and boron in the radioactive waste glass.

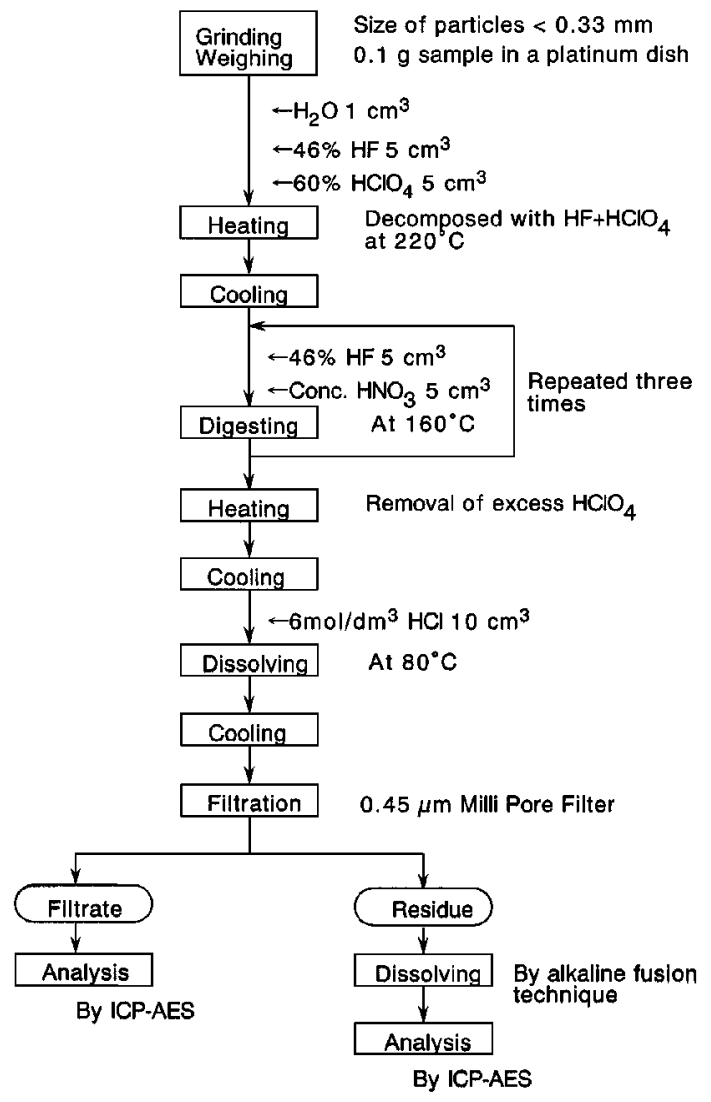

Fig. 3 Procedure of acidic decomposition technique for determination of elements in the radioactive waste glass.

inactive glass samples were prepared for the chemical analysis in the same way as the WVP-waste glass sample.

\section{Determination of elements}

The dissolved solutions were analyzed with an ICPatomic emission spectrometer in a glove box. The instrument (Shimadzu Corp. ICP-1000-II) has two spectrometers: one is a computer-controlled monochromator with range of optimum efficiency " 163 - 458 nm"; the other is a manually-operated monochromator with range of optimum efficiency " $190-768 \mathrm{~nm}$ ". The latter monochrometor, being suitably equipped with a photomultiplier for measurements at long wavelengths, allowed the determination of elements in the long wavelength region such as $\mathrm{Na}(588.995 \mathrm{~nm})$ and $\mathrm{Li}$ $(670.785 \mathrm{~nm})$.

Modifications were made to the torch box and matching network to allow them to be installed in a glove box. This allowed the analysis of radioactive samples during the "hot" operations. Some of this type of instrument are installed in other countries, but in Japan such ICP-spectrometers are few. The instrument and operating conditions are summarized in Table 1. The wavelengths of elements measured by ICP-AES are shown in Table 2. The determination of elements was carried out using the calibration curves prepared by the standard solutions described in the previous section. 
Table 1 Specification and operating condition of ICP-AES

\begin{tabular}{ll}
\hline Model & $\begin{array}{l}\text { Shimadzu ICP 1000-II modified to } \\
\text { be installed in a glove box }\end{array}$ \\
Plasma source & $27.12 \mathrm{MHz}$ \\
Frequency & $1.2 \mathrm{~kW}$ \\
RF power & $15 \mathrm{dm}^{3} / \mathrm{min}$ \\
Coolant gas flow rate & $1.2 \mathrm{dm}^{3} / \mathrm{min}$ \\
Plasma gas flow rate & $1.0 \mathrm{dm}^{3} / \mathrm{min}$ \\
Carrier gas flow rate & concentric glass nebulizer \\
Nebulizer & $2.5 \mathrm{dm}^{3} / \mathrm{min}$ \\
Sample uptake rate & \\
& \\
Spectrometer & $3600 \mathrm{grooves} / \mathrm{mm}$ \\
Main-grating & $1 \mathrm{~m}$ \\
Focal length & $0.22 \mathrm{~nm} / \mathrm{mm}$ \\
Dispersion & $1800 \mathrm{grooves} / \mathrm{mm}$ \\
Sub-grating & $1 \mathrm{~m}$ \\
Focal length & $0.44 \mathrm{~nm} / \mathrm{mm}$ \\
Dispersion &
\end{tabular}

\section{Results and Discussion}

Analytical results of reference material and simulated inactive waste glasses

In order to evaluate the accuracy of the presented analytical method, a reference material of glass (NIST SRM1412) and the simulated inactive waste glass were analyzed by the present method. Five samples of each reference glass were separately decomposed for the
Table 2 Wavelength of elements measured by ICP-AES

\begin{tabular}{cccc}
\hline Element & $\begin{array}{c}\text { Wavelength/ } \\
\mathrm{nm}\end{array}$ & Element & $\begin{array}{c}\text { Wavelength/ } \\
\mathrm{nm}\end{array}$ \\
\hline $\mathrm{Li}$ & 670.785 & $\mathrm{Ni}$ & 221.647 \\
$\mathrm{~B}$ & 249.773 & $\mathrm{Sr}$ & 407.771 \\
$\mathrm{Na}$ & 588.995 & $\mathrm{Zr}$ & 343.823 \\
$\mathrm{Mg}$ & 279.553 & $\mathrm{Mo}$ & 284.823 \\
$\mathrm{Al}$ & 396.152 & $\mathrm{La}$ & 333.749 \\
$\mathrm{Si}$ & 251.611 & $\mathrm{Ce}$ & 413.765 \\
$\mathrm{P}$ & 213.618 & $\mathrm{Nd}$ & 430.358 \\
$\mathrm{Cr}$ & 267.716 & $\mathrm{U}$ & 367.007 \\
$\mathrm{Fe}$ & 259.940 & & \\
\hline
\end{tabular}

determination of elements. The ICP-AES measurement of each glass decomposition solution is repeated 5 times. Analytical results of both samples are shown in Table 3. The analytical value and reproducibility are represented by the average and standard deviation $(\sigma)$ from five measurements on five samples, respectively. For the simulated waste glass sample, the relative standard deviation (RSD,\%) of each component is listed in the table. Concerning the NIST SRM1412, the deviation (\%) of analytical value from the certified value is also shown in Table 3.

The analytical results of the NIST SRM1412 except for $\mathrm{Na}$ agreed within $2 \%$ of the certified values. The slightly large deviation of $\mathrm{Na}$ may be attributed to the contamination during the procedure of sample preparation in shielded cells. In the case of analysis of the

Table 3 Analytical results of NIST Standard Reference Material-1412 and simulated waste glass

\begin{tabular}{|c|c|c|c|c|c|c|}
\hline \multirow{2}{*}{$\begin{array}{l}\text { Element } \\
\text { (oxide) }\end{array}$} & \multicolumn{3}{|c|}{ NIST SRM 1412} & \multicolumn{3}{|c|}{ Simulated waste glass ${ }^{\mathrm{a}}$} \\
\hline & $\begin{array}{l}\text { Certified value } \\
\quad(\mathrm{wt} \%)\end{array}$ & $\begin{array}{c}\text { Analytical result }(\mathrm{wt} \%) \\
\text { Av. } \pm \sigma\end{array}$ & $\begin{array}{l}\text { Deviation } \\
\quad(\%)\end{array}$ & $\begin{array}{l}\text { Expected value } \\
\quad(\mathrm{wt} \%)\end{array}$ & $\begin{array}{c}\text { Analytical result }(\mathrm{wt} \%) \\
\text { Av. } \pm \sigma\end{array}$ & $\operatorname{RSD}(\%)$ \\
\hline $\mathrm{Li}_{2} \mathrm{O}$ & - & - & - & 3.3 & $3.50 \pm 0.11$ & 3.1 \\
\hline $\mathrm{B}_{2} \mathrm{O}_{3}$ & 4.53 & $4.47 \pm 0.11$ & -1.3 & 19.1 & $18.96 \pm 0.22$ & 1.2 \\
\hline $\mathrm{Na}_{2} \mathrm{O}$ & 4.69 & $4.94 \pm 0.14$ & +5.3 & 9.9 & $9.88 \pm 0.39$ & 3.9 \\
\hline $\mathrm{MgO}$ & - & - & - & 2.8 & $2.87 \pm 0.09$ & 3.1 \\
\hline $\mathrm{Al}_{2} \mathrm{O}_{3}$ & 7.52 & $7.48 \pm 0.09$ & -0.53 & 3.2 & $3.42 \pm 0.11$ & 3.2 \\
\hline $\mathrm{SiO}_{2}$ & 42.38 & $41.73 \pm 1.25$ & -1.5 & 55.1 & $53.34 \pm 0.40$ & 0.75 \\
\hline $\mathrm{P}_{2} \mathrm{O}_{5}$ & - & - & - & 0.1 & $0.23 \pm 0.01$ & 4.3 \\
\hline $\mathrm{Cr}_{2} \mathrm{O}_{3}$ & - & - & - & 0.3 & $0.30 \pm 0.006$ & 2.0 \\
\hline $\mathrm{Fe}_{2} \mathrm{O}_{3}$ & - & - & - & 1.5 & $1.55 \pm 0.07$ & 4.5 \\
\hline $\mathrm{NiO}$ & - & - & - & 0.2 & $0.19 \pm 0.006$ & 3.2 \\
\hline $\mathrm{SrO}$ & 4.55 & $4.60 \pm 0.04$ & +1.1 & 0.1 & $0.15 \pm 0.006$ & 4.0 \\
\hline $\mathrm{ZrO}_{2}$ & - & - & - & 0.7 & $0.74 \pm 0.04$ & 5.4 \\
\hline $\mathrm{MoO}_{3}$ & - & - & - & 0.7 & $0.79 \pm 0.03$ & 3.8 \\
\hline $\mathrm{La}_{2} \mathrm{O}_{3}$ & - & - & - & 0.2 & $0.23 \pm 0.006$ & 2.6 \\
\hline $\mathrm{CeO}_{2}$ & - & - & - & 0.4 & $0.44 \pm 0.02$ & 4.5 \\
\hline $\mathrm{Nd}_{2} \mathrm{O}_{3}$ & - & - & - & 0.7 & $0.70 \pm 0.02$ & 2.9 \\
\hline $\mathrm{UO}_{2}$ & - & - & - & - & - & - \\
\hline
\end{tabular}

a. This glass was produced by diluting the simulated waste glass (BC517) with the base glass. Expected values were estimated from the analytical compositions of BC517 glass and base glass. "Av.", " $\sigma$ " and "RSD" represent the average, standard deviation and relative standard deviation from five measurements on five samples, respectively. "Deviation" represents the deviation of average value from the certified value for the NIST SRM 1412. 
waste glass samples, some special precautions for removing the $\mathrm{Na}$ contaminants were taken, e.g. careful cleaning of glassware and using Teflon vessels for chemical agents. As for the reproducibility of determination, five elements of the NIST SRM1412 showed relative standard deviations in the $0.9-3 \%$ range. Both the accuracy and reproducibility are sufficient to indicate that the presented analytical method with the remote sample preparation in shielded cells is applicable to the determination of elements in the radioactive waste glass sample.

Analytical results of the simulated inactive waste glass indicate that there are no significant problems in the present analytical procedure applied to the waste glass. All elements show good reproducibility of less than $6 \%$ RSD. The expected values of the composition of this waste glass were provided by BNFL. This waste glass was produced at the BNFL's Full Scale Inactive Facility by diluting the crushed waste glass (BC517) with the base glass in the ratio of $50: 50$. The expected values were estimated from the analytical compositions of the BC517 waste glass and base glass. As can be seen from Table 3, the analytical results are closely related to the expected values.

The concentration of each element in the blank solutions throughout all analytical procedures was less than its detection limit of ICP-AES, except for $\mathrm{Na}$. The blank concentration of $\mathrm{Na}$ in the normal analytical procedure was about $4 \%$ of the concentration of sample solution due to the contamination. However, by the special precautions described above its concentration decreased to less than the detection limit of ICP-AES.

\section{Analytical results of the WVP-waste glass}

As can be seen from Table 4, all elements except for $\mathrm{P}$ and $\mathrm{Cr}$ show good reproducibility (less than $6 \%$ of $\mathrm{RSD})$. The large RSD of $\mathrm{P}$ is mainly attributed to the low sensitivity of ICP-AES (a detection limit of P: 0.1 $\mathrm{g} / \mathrm{m}^{3}$ ). The slightly large RSD of $\mathrm{Cr}$ probably results from sophisticated analytical procedures derived from the fact that $\mathrm{Cr}$ is distributed in both the dissolved solution and insoluble residue by the acidic decomposition of the radioactive waste glass sample. Incidentally, about $13 \mathrm{wt} \%$ of total $\mathrm{Cr}$ content of the radioactive waste glass sample was contained in the insoluble residue. The major components of insoluble residue were found to be platinum group elements such as $\mathrm{Ru}$, $\mathrm{Rh}$ and Pd by the qualitative analysis with ICP-AES.

The total oxide contents of seventeen elements determined were $94.86 \mathrm{wt} \%$. This means that the WVPwaste glass contains other oxides of elements such as fission products ( $\mathrm{Rb}, \mathrm{Y}, \mathrm{Ru}, \mathrm{Rh}, \mathrm{Pd}, \mathrm{Cs}, \mathrm{Ba}, \mathrm{Pr}, \mathrm{Sm}, \mathrm{Eu}$, etc.) and TRU elements ( $\mathrm{Np}, \mathrm{Pu}, \mathrm{Am}, \mathrm{Cm}$, etc.). These elements were not determined in the present work.

Table 4 also shows the comparison between the present analytical results in chemical composition and the data estimated by BNFL. In Table 4, the "good correlation" means that the BNFL value is within the interval of $\pm 3 \sigma$ of the analytical value and/or the analytical
Table 4 Analytical results of WVP-radioactive waste glass sample and comparison between present results and data estimated by BNFL

\begin{tabular}{|c|c|c|c|c|}
\hline $\begin{array}{l}\text { Element } \\
\text { (Oxide) }\end{array}$ & $\begin{array}{l}\text { Analytical result } \\
\text { (wt } \% \text { ) } \\
\text { Av. } \pm \sigma\end{array}$ & $\begin{array}{c}\mathrm{RSD} \\
(\%)\end{array}$ & $\begin{array}{c}\text { Value estimated } \\
\text { by BNFL (wt } \%) \\
\text { Av. } \pm \sigma\end{array}$ & Correlation $^{\mathrm{a}}$ \\
\hline $\mathrm{Li}_{2} \mathrm{O}$ & $3.82 \pm 0.11$ & 2.9 & $4.02 \pm 0.12$ & good \\
\hline $\mathrm{B}_{2} \mathrm{O}_{3}$ & $16.0 \pm 0.17$ & 1.1 & $16.66 \pm 0.1$ & fair \\
\hline $\mathrm{Na}_{2} \mathrm{O}$ & $8.24 \pm 0.14$ & 1.7 & $8.20 \pm 0.10$ & good \\
\hline $\mathrm{MgO}$ & $5.71 \pm 0.04$ & 0.70 & $5.88 \pm 0.17$ & fair \\
\hline $\mathrm{Al}_{2} \mathrm{O}_{3}$ & $5.71 \pm 0.06$ & 1.0 & $5.67 \pm 0.18$ & good \\
\hline $\mathrm{SiO}_{2}$ & $46.8 \pm 1.1$ & 2.3 & $45.74 \pm 0.1$ & good \\
\hline $\mathrm{P}_{2} \mathrm{O}_{5}$ & $0.02 \pm 0.007$ & 35 & - & - \\
\hline $\mathrm{Cr}_{2} \mathrm{O}_{3}$ & $0.31 \pm 0.027$ & 8.7 & $0.26 \pm 0.008$ & good \\
\hline $\mathrm{Fe}_{2} \mathrm{O}_{3}$ & $2.45 \pm 0.14$ & 5.7 & $2.49 \pm 0.087$ & good \\
\hline $\mathrm{NiO}$ & $0.26 \pm 0.007$ & 2.7 & $0.234 \pm 0.008$ & fair \\
\hline $\mathrm{SrO}$ & $0.23 \pm 0.001$ & 0.43 & - & - \\
\hline $\mathrm{ZrO}_{2}$ & $1.06 \pm 0.02$ & 1.9 & $1.16 \pm 0.031$ & fair \\
\hline $\mathrm{MoO}_{3}$ & $1.42 \pm 0.02$ & 1.4 & $1.37 \pm 0.05$ & good \\
\hline $\mathrm{La}_{2} \mathrm{O}_{3}$ & $0.42 \pm 0.007$ & 1.7 & - & - \\
\hline $\mathrm{CeO}_{2}$ & $0.80 \pm 0.011$ & 1.4 & - & - \\
\hline $\mathrm{Nd}_{2} \mathrm{O}_{3}$ & $1.27 \pm 0.03$ & 2.4 & $1.32 \pm 0.037$ & good \\
\hline $\mathrm{UO}_{2}$ & $0.34 \pm 0.005$ & 1.5 & $0.371 \pm 0.011$ & fair \\
\hline Total & 94.86 & & & \\
\hline
\end{tabular}

"Av.", " $\sigma$ " and "RSD" represent the average, standard deviation and relative standard deviation from five measurements on five samples, respectively.

a. "Good correlation" represents the case that the value estimated by BNFL is within the interval of $\pm 3 \sigma$ of the analytical value and/or the analytical value is within $\pm 3 \sigma$ of the estimated value. "Fair correlation" represents the case that the $\pm 3 \sigma$ of the estimated value overlaps the interval of $\pm 3 \sigma$ of the analytical value.

value is within $\pm 3 \sigma$ of BNFL value ( $\sigma$ represents the standard deviation of chemical analysis). The "fair correlation" means that the $\pm 3 \sigma$ of the BNFL value is within the interval of the $\pm 3 \sigma$ of the analytical value. The analytical values of all elements are in good or fair agreement with the values estimated by BNFL, which were calculated from the analytical results of glass frit and the HLLW used in the production of the WVPwaste glass sample. The glass frit produced by a manufacturer was analyzed in an independent laboratory. The chemical composition of HLLW was determined by ICP-AES in an accredited laboratory on the Sellafield site. The data for P, Sr, La and Ce were not provided by BNFL because BNFL's routine analysis of the HLLW does not include chemical analysis for those elements.

The analytical value of $B$ is lower than the expected value for $B$. This may be caused by volatilization of a small part of B during decomposition of the sample by fusion with sodium peroxide. Boron is one of the volatile elements during melting at high temperature. ${ }^{4}$ The analytical results on the reference material of glass (NIST SRM1412) using the same method (Table 3) implied a slight effect of volatilization of $\mathrm{B}$, i.e. the deviation of analytical value of $B$ from certified value for the reference material of glass was negative. 
The values analyzed for $\mathrm{Cr}$ and $\mathrm{Ni}$ are higher than expected for both these elements. The differences in $\mathrm{Cr}$ and Ni may be due to the presence of corrosion products from the glass melter in small amounts in the radioactive waste glass. The glass melter of the WVP is made of INCONEL-601 which contains $\mathrm{Ni}$ and $\mathrm{Cr}$ as the main components. ${ }^{5}$

We were greatly indebted to Messrs. H. Umehara, O. Kikuchi, H. Takano and H. Miura of Chiyoda Maintenance Ltd. for the sample preparation with the in-cell apparatus. We would like to thank Messrs. S. Matsumoto and Y. Kawasaki of WASTEF at JAERI for their valuable discussions.

This work was performed at JAERI and BNFL under the auspices of the Science and Technology Agency of Japan (STA).
2. P. Cheron et al., "Scientific Basis for Nuclear Waste Management XVIII", ed. T. Murakami and R. Ewing, Materials Research Society, Mat. Res. Soc. Symp. Proc. Vol. 353, p. 55, 1995.

3. T. Banba, H. Hagiya, Y. Tamura and C. Yonezawa, Bunseki Kagaku, 42, 317 (1993).

4. M. Asano, T. Kou and Y. Mizutani, J. Non-Cryst. Solids, 112, 381 (1989).

5. ASTM B 166, "Nickel-Chromium-Iron Alloys (UNS No. 6600, No. 6601, No. 6690, No. 6025, and No. 6045) and Nickel-Chromium-Cobalt-Molybdenum Alloy (UNS No. 6617) Rod, Bar, and Wire", American Society for Testing and Materials, West Conshohocken, PA, USA, 1996.

(Received November 4, 1997) (Accepted January 29, 1998)

\section{References}

1. W. Baehr, IAEA Bull., 31 (4), 43 (1989). 